\title{
Phytochemical Screening of Some Selected Nigerian Medicinal Plants
}

\author{
Usman Yahaya ${ }^{1,}$, , Maryam Sani Lawal ${ }^{2}$, Samiratu Abubakar ${ }^{3}$, Suleiman Rafiu Adeyemi $^{4}$, \\ Raihana Abdullahi Idris ${ }^{5}$, Faiza Ibrahim Saad ${ }^{1}$ \\ ${ }^{1}$ Shelterbelt Research Station, Forestry Research Institute of Nigeria, Kano, Nigeria \\ ${ }^{2}$ Department of Biochemistry, Ahmadu Bello University, Zaria, Nigeria \\ ${ }^{3}$ Yahaya Hamza Institute of Technology, Mando-Afaka, Kaduna, Nigeria \\ ${ }^{4}$ Trial Afforestation Research Station, Forestry Research Institute of Nigeria, Kaduna, Nigeria \\ ${ }^{5}$ Department of Botany, Ahmadu Bello University, Zaria, Nigeria
}

Email address:

usmanyahayaks@gmail.com (U. Yahaya)

${ }^{*}$ Corresponding author

\section{To cite this article:}

Usman Yahaya, Maryam Sani Lawal, Samiratu Abubakar, Suleiman Rafiu Adeyemi, Raihana Abdullahi Idris, Faiza Ibrahim Saad. Phytochemical Screening of Some Selected Nigerian Medicinal Plants. International Journal of Bioorganic Chemistry.

Vol. 5, No. 1, 2020, pp. 1-4. doi: 10.11648/j.ijbc.20200501.11

Received: November 28, 2019; Accepted: December 23, 2019; Published: January 6, 2020

\begin{abstract}
Medicinal plants play an essential role in the development of human life. Medicinal plants are used by local people to cure various diseases. All the plants in this study were biologically active and were used for different ailments. Phytochemicals are bioactive compounds obtained from the plant and are widely applied in the traditional herbal medicine. Preliminary screening of phytochemicals is a valuable step in the detection of bioactive principles present in medicinal plants and may lead to novel environmentally friendly drug discovery. The objective of the study was to screen such phytochemicals in selected Nigerian medicinal plants. Fresh plant material (leaves) were collected and processed prior to phytochemical screening. Alkaloids, glycosides, flavonoids, saponin, tannin, steroids, phenols and protein distribution in six medicinal plants belonging to different families were assessed and compared using aqueous and ethanolic leave extract. The medicinal plants investigated were Parkia biglobosa, Boswellia dalzielli, Carica papaya, Bridelia feruginea, Acalypha wilkesinia and Anogeissus leiocarpus. It was observed that almost all the plant leave extract (aqueous and ethanolic) contains the important phytochemicals like alkaloids, saponin, tannin and phenol. It was concluded that the plants studied were rich in phytochemicals with significant pharmacological and medicinal applications. Hence, the use of the medicinal plant should be encouraged.
\end{abstract}

Keywords: Phytochemical, Medicinal Plants, Extract

\section{Introduction}

Plants derived substances have recently become of great interest due to their versatile uses [1]. Herbal medicine plays an important role in healthy being of individuals. Medicinal plants are natural plant materials which are used for treatment of ailments [2]. Medicinal plants are cheap and renewable sources of pharmacologically active substances and are known to produce certain chemicals that can be used to cure diseases [3]. Chemical substances in plants play a definite physiological role on human body [4]. Many plants in Africa have been used as sources of remedies for many diseases. The long term use of medicinal plants is a sure indication of their value and usefulness in the future. In modern medicine, the importance of medicinal plants is increasing with pharmaceutical and cosmetic industries increasingly using plant resources from rural or unpolluted areas [5]. Nature has been a source of medicinal agents for thousands of years and generally produces many secondary metabolites which constitute important leads for the development of new environmentally friendly microbicides, pesticides, herbicides and many pharmaceutical drugs [6].

Phytochemicals also known as secondary metabolites originated from the plant sources which are formed during 
normal metabolic processes [7]. Secondary metabolites such as alkaloid, flavonoids, glycosides, phenols, tannin, terpenes and terpenoids are economically important in the production of drugs, flavour, dye, pesticides and food additives. The potential of the phytochemicals have large scale pharmacological and biological activities. Knowledge of organic components of plants is important, not only for the discovery of therapeutic agents but also because such information can be used in disclosing new sources of economic materials which can serve as a precursor for synthesis of complex chemical substances [8]. Leaves of Parkia biglobosa, Boswellia dalzielli, Carica papaya, Bridelia feruginea, Acalypha wilkesinia and Anogeissus leiocarpus are extensively used for herbal medicine in Nigeria. Considering the role of phytochemicals and other important constituents of these plants and their wide application by the local communities and practitioners for a variety of ailments, it is important to provide scientific data base line which may play a significant role in knowing the quantities of these phytochemicals. Therefore, the study aims at providing information on the phytochemical constituents of some selected Nigerian Medicinal plants.

\section{Materials and Methods}

\subsection{Collection, Identification and Processing of Plant Materials}

Fresh leaves of the plants were collected from Afaka Forest Reserve, Kaduna. The plants were presented to confirm the identities of the plants at Department of Biological Sciences, Nigerian Defence Academy, Kaduna. The plants were air dried and milled into coarse powder with an electric blender.

\subsection{Extraction Procedure}

Aqueous and ethanolic extracts of the plants were prepared using the method described by [9] as follows:

\subsubsection{Aqueous Extract}

One hundred grams of the blended sample was measured into a conical flask and $1000 \mathrm{ml}$ of sterile distilled water was added, covered with a cork, and was mixed together properly and left in a shaker at 100 revolution per minute for 24 hours. The sample was filtered and squeezed through four layers of muslin cloth. The extract was then sterilized and concentrated at $40^{\circ} \mathrm{C}$, the final extracts obtained for phytochemical analysis.

\subsubsection{Ethanolic Extract}

One hundred grams of the blended sample was measured into a conical flask and $1000 \mathrm{ml}$ of ethanol was added; covered with a cork, and left on a shaker at 100 r.p.m. for 24 hours after which the extract was filtered and squeezed through four layers of muslin cloth. The extract was then sterilized and concentrated at $40^{\circ} \mathrm{C}$, the final extracts obtained for phytochemical analysis.

\subsection{Phytochemical Screening}

The extracts were analyzed for the presence of Alkaloids, Glycoside, Flavoniod, Saponin, Tannnin, Steriods, Phenols and Protein in accordance to the methods described by $[10,11]$.

\subsubsection{Detection of Alkaloids (Wagner's Reagent Test)}

Extracts were dissolved individually in dilute Hydrochloric acid and filtered and treated with Wagner's reagent (Iodine in Potassium Iodide). Formation of brown/reddish precipitate indicates the presence of alkaloids.

\subsubsection{Detection of Glycosides: (Keller-Killani Test)}

Five $\mathrm{ml}$ of each extracts was treated with $2 \mathrm{ml}$ of glacial acetic acid containing one drop of ferric chloride solution. This was underlayed with $1 \mathrm{ml}$ of concentrated sulphuric acid. A brown ring of the interface indicates a deoxysugar characteristic of cardenolides. A violet ring may appear below the brown ring, while in the acetic acid layer, a greenish ring may form just gradually throughout thin layer.

\subsubsection{Detection of Flavonoids (Alkaline Reagent Test)}

Extracts were treated with few drops of sodium hydroxide solution. Formation of intense yellow colour, which becomes colorless on addition of dilute acid, indicates the presence of flavonoids.

\subsubsection{Detection of Saponins (Foam Test)}

$0.5 \mathrm{gm}$ of extract was shaken with $2 \mathrm{ml}$ of water. If foam produced persists for ten minutes it indicates the presence of saponins.

\subsubsection{Detection of Phenols (Ferric Chloride Test)}

Extracts were treated with 3-4 drops of ferric chloride solution. Formation of bluish black colour indicates the presence of phenols.

\subsubsection{Detection of Tannins}

Extracts were mixed with $2 \mathrm{ml}$ of $2 \%$ solution of $\mathrm{FeCl}_{3}$. A blue-green or blue-black coloration indicated the presence of and tannins.

\subsubsection{Detection of Steroids}

Two $\mathrm{ml}$ of acetic anhydride was added to $0.5 \mathrm{~g}$ of extract with $2 \mathrm{ml}$ of sulphuric acid. The colour changed from violet to blue or green in some samples indicating the presence of steroids.

\subsubsection{Detection of Proteins (Ninhydrin Test)}

To the extract, $0.25 \% \mathrm{w} / \mathrm{v}$ ninhydrin reagent was added and boiled for few minutes. Formation of blue colour indicates the presence of amino acid.

\section{Result and Discussion}

Yield \% obtained from plant extracts

The percentage yield obtained from the aqueous and ethanolic extracts were recorded in (Table 1) where Anogeissus leiocarpus has the highest percentage yield obtained such (20.4\%). 
Table 1. Yield \% obtained from plant extracts.

\begin{tabular}{lll}
\hline Plants & Ethanolic extracts yield (\%) & Aqueous extracts yield (\%) \\
\hline Boswellia dalzielli & 16.6 & 19.9 \\
Carica papaya & 17.3 & 18.3 \\
Parkia biglobosa & 14.2 & 17.5 \\
Acalypha wilkesinia & 9.9 & 16.6 \\
Anogeissus leiocarpus & 20.4 & 18.6 \\
Bridelia feruginea & 11.8 & 14.2 \\
\hline
\end{tabular}

Phytochemical Screening

Phytochemical screening of the plant extracts revealed the presence of phytochemicals such as alkaloids, tannins while saponins, phenols, glycosides, flavonoids, steroids and proteins in some of the plant especially in the aqueous extracts (Tables 2 and 3).

Table 2. Quantitative analysis of the phytochemicals of the ethanolic leave extracts of some medicinal plants.

\begin{tabular}{|c|c|c|c|c|c|c|c|c|}
\hline Plants & Alkaloid & Glycoside & Flavonoid & Saponin & Tannin & Steroids & Phenols & Protein \\
\hline BDL & + & - & + & + & + & + & + & - \\
\hline CPL & + & + & - & + & + & + & + & - \\
\hline PBL & + & + & + & + & + & - & - & - \\
\hline AWL & + & + & + & + & + & - & + & - \\
\hline ALL & + & + & + & + & + & + & _ & _- \\
\hline BFL & + & + & + & & + & + & & \\
\hline
\end{tabular}

KEY: $\mathrm{BDL}=$ Boswellia dalzielli, $\mathrm{CPL}=$ Carica papaya, $\mathrm{PBL}=$ Parkia biglobosa, $\mathrm{AWL}=\mathrm{Acalypha}$ wilkesinia, $\mathrm{ALL}=\mathrm{Anogeiss}$ (eiocarpus, $\mathrm{BFL}=\mathrm{Bridelia}$ feruginea.

Table 3. Quantitative analysis of the phytochemicals of the aqueous leave extracts of some medicinal plants.

\begin{tabular}{|c|c|c|c|c|c|c|c|c|}
\hline Plants & Alkaloid & Glycoside & Flavonoid & Saponin & Tannin & Steroids & Phenols & Protein \\
\hline BDL & + & - & . & + & + & - & + & + \\
\hline CPL & + & + & - & + & _ & - & _ & _- \\
\hline PBL & + & + & + & + & + & + & + & + \\
\hline AWL & + & + & + & + & + & + & + & + \\
\hline ALL & + & + & + & + & + & + & + & + \\
\hline BFL & + & + & + & + & + & + & + & \\
\hline
\end{tabular}

KEY: $\mathrm{BDL}=$ Boswellia dalzielli, $\mathrm{CPL}=$ Carica papaya, $\mathrm{PBL}=$ Parkia biglobosa, $\mathrm{AWL}=\mathrm{Acalypha}$ wilkesinia, $\mathrm{ALL}=\mathrm{Anogeiss}$ (eiocarpus, $\mathrm{BFL}=\mathrm{Bridelia}$ feruginea.

Currently, herbal products are being used as a source in medicine. The medicinal properties of plants have been part of ancient knowledge, and modern medicine benefits from them. In this sense, phytochemicals and their derivatives have been an extraordinary source of principal compounds for therapeutics and drug development.

Phytochemical screening of Parkia biglobosa, Boswellia dalzielli, Carica papaya, Bridelia feruginea, Acalypha wilkesinia and Anogeissus leiocarpus leaves extracts showed presence of some phyto compounds (Tables 2 and 3). This finding agrees with the finding of [12] who reported that Boswellia dalzielli extract contains alkaloid, tannin, steroids, flavonoids and saponin. Similarly, [13] also performed phytochemical analysis of parkia biglobosa which showed the presence of alkaloid, flavonoids, saponin and phenols. Carica papaya contains alkaloids, flavonoids, steroids and tannin as reported by [14]. Aqueous leaves extract of Acalypha wilkesinia contains flavonoids, glycosides, saponin and alkaloids as reported by [15]. Findings on Angeissus leiocorpus leaves extract (aqueous and ethanolic) revealed the presences of saponins, tannin, glycosides, flavonoids and alkaloids which agrees with this research [16]. The finding in this research agrees with the findings of [17] who reported that Bridelia feruginea extract contains alkaloids, gylcosides, flavonoids, phenols and tannin. Alkaloids have been associated with medicinal uses with cytotoxicity as one of their common biological properties

\section{Conclusion}

Extraction of the selected medicinal plant and preliminary phytochemical analysis of both plants used in this research shows that the plants are reached in important phytochemicals that can play an important role in the manufacturing of new drugs. The results of this investigation suggest that the use of some of these plants in traditional medicine can be scientifically justified. Medicinal plants are gift from nature; its uses should be encouraged, especially in the production of drugs. There should be a synergy between traditional medicine practice and the orthodox counterpart for the safety of human life. Bioactive compounds from plants in purified form, can replace synthetic drugs. The results of this study revealed the presence of medicinally important constituents in the leave extracts which is nearly similar to previous phytochemical analysis. Several studies carried out by numerous authors are in agreement with reference of this 
view. Therefore, these plants could be seen as a good source of bioactive chemical compounds which can be of great value in drug production.

\section{References}

[1] Prashant, T., Bimlesh, K., Mandeep, K., Curpreet, K. and Harleen, K (2011). Phytochemical Screening and Extraction: A Review. International Pharmaceutica Sciencia 1 (1): 98106.

[2] Fatemeh, J. K., Zahra, L and Hossein, A. K (2018). Medicinal Plamts; Past and Future Perspective. Journal of Herbal Pharmacology 7 (1): 1-7.

[3] Basile, A., Giordanes, S., Lopez-Sazez, J. A and Cobianchi, R. C (1999). Antibacterial Activity of Pura Flavoniods Isolated from mosses. Phytochemistry 52: 1479-1482.

[4] Edeogo, H. O., Okwu, D. E and Mbaebie, B. O (2005). Phytochemical Constituents of some Nigerian Medicinal plants. African Journal of Biotechnology 4 (7): 685-688.

[5] Ndam, L. M., Mig, A. M., Fongod, A. G. M., Tening, A. S., Tonjock, R. K., Enang, T. E. and Fujii, Y (2014). Phytochemical screening of the bioactive compounds in twenty Camarronian medicinal plants. International Journal of Current Microbiology and Applied Sciences 3 (12): 768778 .

[6] Bobbarala, V., Katikala, P. K, Naidu, K. C. and Penumajji, S (2009). Antifungal activity of selected plant extracts against phytopaathogenic fungi Aspergillus niger. Indian Journal of Science Technology 2: 2-35

[7] Osuntakun, O. I. and Oluwafoise, B, O (2015). Phytochemical Screening of Ten Nigerian Medicinal Plants. International Journal of Multidisciplinary Research and Development 2 (4): 390-396.

[8] Okach, D. O., Nyunja, A. R. O. and Opande, G (2013). Phytochemical Screening of some Wild plants from
Lamiaceae and their role in Traditional Medicine in Uriri District, Kenya. International Journal of Herbal Medicine 1 (5): 135-143.

[9] Barry A. L. and Thornsberry C. (1991). Susceptibility tests: Manual of Clinical Microbiology. $5^{\text {th }}$ ed. Washinghton: America Society for Microbiology.

[10] Sofowara. A, (1993). Medicinal plants and Traditional medicine in Africa. Spectrum Books Ltd, Ibadan, Nigeria. p. 289.

[11] Trease, G. E, \& Evans, M. C. (1983). Textbook of Pharmacognosy (12th ed.) London: Bailiere, Tindal. pp. 343383.

[12] Uzama, D., Gbubele, J. D, Bwai, M. D and kabir, M, G (2015). Phytochemical, Nutritional and Antimicrobial Screening of Hexane, Ethyl Acetate and Ethanolic Extracts of Boswellia dalzielli leaves and bark. American Journal of Bioscience and bioengineering 3 (5): 76-79.

[13] Usman, Y., Samiratu, A. and Aminu, S. (2019). Antifungal Activity of Parkia biglobosa Extract on Pathogenic Strain of Candida albicans. Journal of Applied Sciences 19: 235- 240.

[14] Snigdha, S., Ravish, M., Narayau, G., Manisha, N., Nilotpol, K and Kishore, D (2019). Phytochemical Analysis of Papaya leaf extract; Screening Test. E-Dental Science 18 (3): 485490.

[15] Madziga, H. A., Sanni, S and Sandabe, U. K. (2010). Phytochemical and Elemental Analysis of Acalypha wilkesinia. Journal of American Science 6 (11): 510-514.

[16] Dayok, O., Dawang, N. and Da'am, C. E (2018). Antimicrobial Activity of leaf extract of Anogeissus leiocarpus on some selected clinical isolate. Journal of Pharmacy and Biological Sciences 13: 36-40.

[17] Temitayo, O. k., Bukola, C. A, Abimbola, O. A (2017). The phytochemical and Antimicrobial Potentials of the Crude Extract of Bridelia ferruginea and the Extra Cellular Biosynthesized Silver Nanoparticles. Journal of advances in Medical and Pharmaceutical Sciences 14 (3). 1-13. 